\title{
Wizyjna kontrola rozmiaru jeziorka spawalniczego w czasie rzeczywistym
}

\section{Real-time vision based control of weld pool size}

\section{Streszczenie}

W artykule omówiono technikę komputerowego przetwarzania obrazów, opartą na pomiarze i kontroli w czasie rzeczywistym powierzchni lub rozmiaru jeziorka spawalniczego od strony źródła ciepła i od strony przetopu.

Wykazano możliwości zastosowania komputerowego przetwarzania obrazu do utrzymania wymiarów przez wykonanie pomiarów oraz sterowanie procesem topienia i formowania spoiny. Opracowano algorytm analizy obrazu oparty na porównywaniu z wzorcem, który może być dobrany dla różnych metod spawania. Regulacja szerokości powierzchni jeziorka spawalniczego od strony źródła ciepła, za pomocą prostego klasycznego algorytmu sterowania ze sprzężeniem zwrotnym, umożliwia polepszenie jednorodności i powtarzalności spoiny przy zmieniających się warunkach odprowadzenia ciepła.
Abstract

A computer vision technique based on the real-time measurement and control of the upper surface or 'topface' weld pool size is discussed. The primary objective has been to demonstrate the feasibility of using vision based image processing to provide measurements and the subsequent control of weld geometrical properties during the weld formation or molten phase.

A novel reference feature correlation based image analysis algorithm has been developed that may be configured to operate with a number of different welding processes. Upper surface weld pool with regulation via a simple classical feedback control algorithm has then been demonstrated to show how this approach may be used to improve weld uniformity and repeatability.

\section{Wstęp}

Opracowano wiele sposobów automatyzacji łukowych metod spawania: od wykorzystania metod sztucznej inteligencji, poprzez automatyzację procesu doboru parametrów spawania, aż do zastosowania czujników kontroli i monitorowania procesu spawania oraz zaawansowanych strategii kontroli, zaprojektowanych do przetwarzania informacji z czujników [1:7]

W dowolnym układzie regulacji z czujnikami uzyskiwanie stabilnych pomiarów jest często trudne do osiągnięcia ze względu na łuk spawalniczy, który wytwarza zarówno ciepło, jak i intensywne światło.

Omówiono więc podejście uniwersalne polegające na komputerowym przetwarzaniu wysokiej jakości obrazu spoiny od strony źródła ciepła. Jego celem jest dostarczenie, w czasie rzeczywistym, wiarygodnych pomiarów szerokości powierzchni jeziorka spawalniczego od strony źródła ciepła, których można użyć w systemie sterowania procesem.

System sterowania procesem spawania został zaprojektowany do regulowania szerokości powierzchni jeziorka od strony źródła ciepła tak, aby umożliwić uzyskiwanie bardziej jednorodnych spoin w zmieniających się warunkach ich układania.

Możliwe źródła zakłóceń procesu spawania w systemie niekontrolowanym są następujące: niejednorodne pochłanianie ciepła w związku z ustawieniem uchwytu spawalniczego

Prof. William Lucas, Dan Bertaso, inż. Geoff Melton - TWI, Cambridge, Wielka Brytania, prof. Jeremy Smith, C. Balfour - Uniwersytet w Liverpool. różnice we właściwościach materiału podstawowego i systematyczne odchylenia w procesie spawania lub wybór niestabilnych parametrów jarzenia się łuku.

Kluczowym czynnikiem udanej konfiguracji systemu czujników wizyjnych jest generowanie stabilnych, wysokiej jakości obrazów procesu spawania, które można analizować. Uproszczony schemat ustawienia czujnika powierzchni jeziorka od strony źródła ciepła pokazano na rys. 1.

Przed uchwytem spawalniczym i elementami podawania drutu umieszczono kamerę CCD z systemem soczewek i środkowo przepustowym filtrem podczerwieni. Długość pracy filtra jest bliska obcinanej długości fali kamery, a więc większość światła łuku spawalniczego zostaje zatrzymana. Kamera jest również umieszczona pod kątem do płaszczyzny elementu spawanego, a więc ilość światła łuku, na które

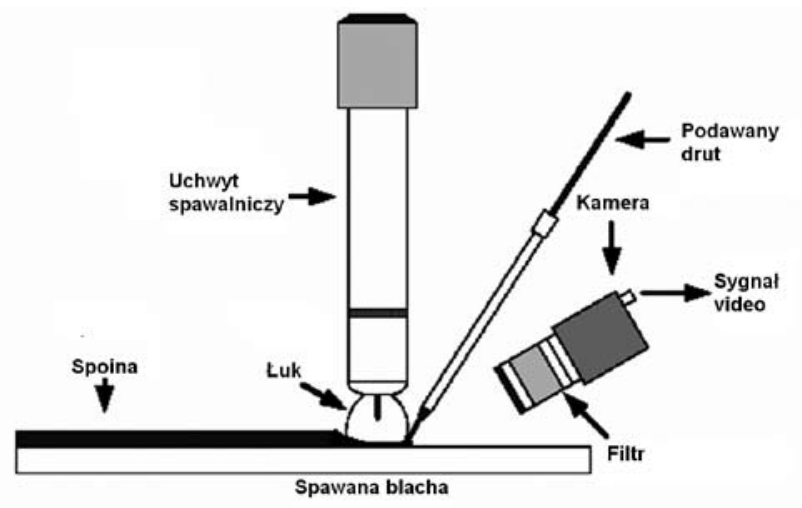

Rys. 1. Ustawienie czujnika lica spoiny spawania łukowego

Fig. 1. Topface sensor arrangement for are welding 
wystawiony jest czujnik kamery, jest nadal ograniczana. Taka konfiguracja czujnika, przez przepuszczenie ograniczonego zakresu światła łuku do oświetlania obszaru obserwowanej spoiny, może wytworzyć wysokiej jakości obrazy ciekłego jeziorka w stanie „łuk włączony”. Eliminuje to konieczność zastosowania dodatkowego źródła światła do oświetlenia jeziorka spawalniczego. Wadą takiego rozwiązania jest jednak to, że ustawienie kamery, stabilność światła łuku oraz właściwości spoiny i materiału rodzimego, takie jak stan powierzchni, będą miały wpływ na jakość tworzonych obrazów. Aby odnieść się do wymienionych problemów, należałoby wykonać serię prób w celu określenia ustawienia kamery względem elementu spawanego, optymalnego z punktu widzenia spójności dostarczanych obrazów.

W opracowaniu opisano, jak obraz lica spoiny od strony źródła ciepła może być przetwarzany w celu wykonania pomiarów geometrycznych w czasie rzeczywistym. Przedstawiono również dobór parametrów i typu układu regulacji procesem ze sprzężeniem zwrotnym, który wykorzystuje pomiary czujnika wizyjnego powierzchni jeziorka spawalniczego od strony źródła ciepła i przetwarza je prostą klasyczną techniką regulacji ze sprzężeniem zwrotnym. Przedstawiono też parametry regulatora ze sprzężeniem zwrotnym procesu spawania, gdzie pomiarów powierzchni jeziorka spawalniczego dokonuje się tradycyjną techniką regulacji.

\section{Digitalizacja i przetwarzanie obrazów}

Uproszczony schemat systemu rejestracji i przetwarzania obrazu pokazano na rys. 2 . Zespolony sygnał wideo z kamery CCD zostaje zarejestrowany i przetworzony na postać cyfrową przez interfejs telewizyjny lub kartę WinTV zainstalowaną w typowym komputerze PC, który na ogół jest wyposażony w system operacyjny Microsoft Windows 2000. Taka karta rejestracyjna efektywnie generuje strumień cyfrowych obrazów wideo z kamery.

Algorytm analizy został wprowadzony w Microsoft Visual $\mathrm{C}++$, który przetwarza cyfrowy strumień wideo na zasadzie klatka po klatce w czasie rzeczywistym z użyciem oprogramowania Video for Windows (VFW) [8, 9]. Dodanie informacji diagnostycznych do przetworzonych klatek wideo przed wyświetleniem ich na monitorze komputera umożliwia monitorowanie działania algorytmu analizy obrazu. Informacje te będą zazwyczaj zawierały kursory, wskazujące zmierzone pozycje krawędzi ciekłego jeziorka przed wyświetleniem przetworzonej klatki. W ten sposób można stworzyć wizualną prezentację działania algorytmu przetwarzającego. Końcowa faza

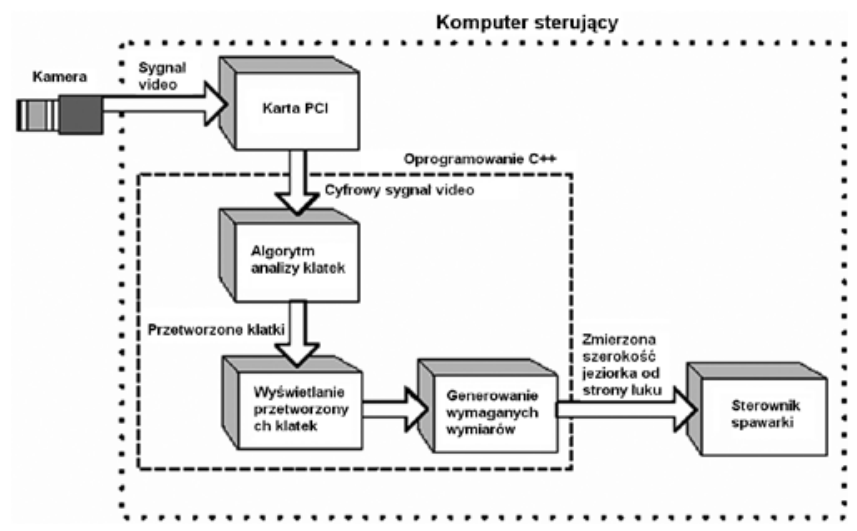

Rys. 2. Rejestracja i przetwarzanie obrazu

Fig. 2. Image capture and processing cyklu przetwarzania klatek z kamery polega na generowaniu pomiarów szerokości ciekłego jeziorka. Wygenerowany pomiar może być następnie dostarczony do systemu sterowania procesem, tak aby było możliwe wdrożenie sterowania szerokością ciekłego jeziorka ze sprzężeniem zwrotnym. System analizy obrazu może przetworzyć obraz analogowy na obraz cyfrowy (zdigitalizować) i przetwarzać zarejestrowane obrazy z maksymalną szybkością klatek kamery, która zazwyczaj wynosi $25 \mathrm{~Hz}$ dla standardowego wideo z przeplotem.

Jeżeli algorytm analizy obrazu może działać w czasie pomiędzy kolejnymi klatkami kamery, to można wykonywać pomiary z szybkością aktualizacji wyjścia równą szybkości klatek kamery. Wdrożona technika analizy obrazu jest oparta na 8-bitowej korelacji intensywności w skali szarości ze zgromadzonymi cechami z obrazów próbnych lub wzorcowych [10]. Ta technika została połączona z serią prostych procedur kalibracji, których użyto w celu ograniczenia liczby danych obrazowych, które mają być przetwarzane w każdej klatce. Na rys. 3 zilustrowano tę metodę $z$ użyciem obrazów lica od strony źródła ciepła, na stop Inconel 718. Kamera obrazująca ma ustaloną pozycję względem uchwytu spawalniczego i elementu spawanego. Umożliwia to „kalibrację” oprogramowania przetwarzającego do analizowania wyłącznie wybranego obszaru obrazu spoiny. Pozycyjna kalibracja algorytmu jest osiągana przez użycie krzyżyka generowanego przez oprogramowanie, który można umieszczać w środku zarejestrowanego obrazu wzorcowego jeziorka spawalniczego, jak pokazano na rys. 3a.

Przetwarzanie kolejnych obrazów rozpoczyna się od lewej poziomej pozycji kalibracji. Pozwala to wykluczyć z przetwarzania większą część zarejestrowanego obrazu, dzięki czemu znacznie polepsza się wydajność algorytmu. Druga faza konfiguracji algorytmu przetwarzającego polega na próbkowaniu pary charakterystycznych cech krawędzi, w formie jednowymiarowych macierzy wartości intensywności z obrazu wzorcowego, jak pokazano na rys. 3c, d. Krzyżyk po lewej stronie na rys. 3b wskazuje środek lewej cechy krawędzi jeziorka spawalniczego, a dwa białe pionowe pasy po każdej stronie krzyżyka przedstawiają granice wydzielanej cechy.

W podobny sposób krzyżyk i pionowe pasy po prawej stronie rys. 3b przedstawiają umieszczenie wydzielanej prawej cechy krawędzi. Wykresy cech wzorcowych dla stopu Inconel 718 , które odnoszą się do obrazów spoiny na rys. 3 , pokazano na rys. $3 \mathrm{c}$ i $3 \mathrm{~d}$.
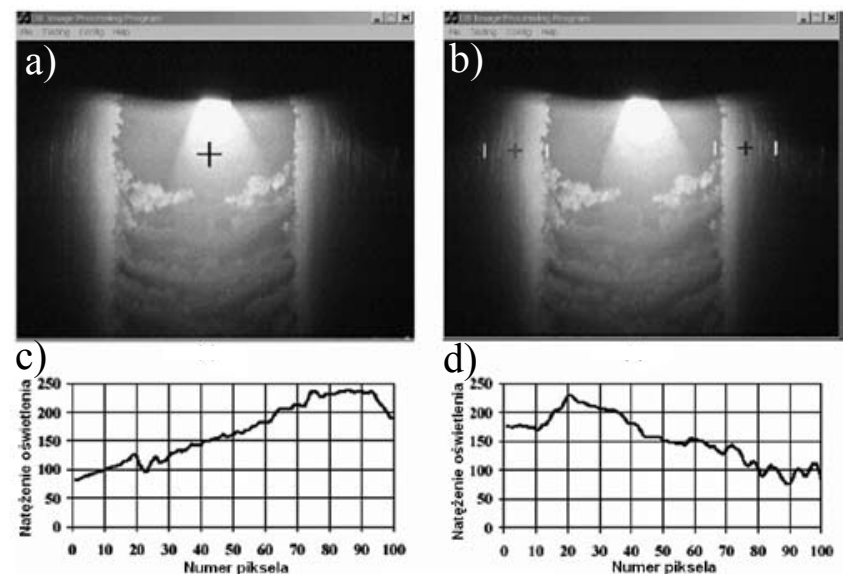

Rys. 3. Korelacja wzorca obrazu: a - kalibracja, b - wydzielenie wzorca (ekstrakcja cech), c - wykres wzorcowy lewej krawędzi jeziorka spawalniczego, d - wykres wzorcowy oświetlenia prawej krawędzi jeziorka spawalniczego

Fig. 3. Image feature correlation, a - calibration, b - feature extraction, $c$ - left extracted feature graph, $d$ - right extracted feature graph 
Po dostarczeniu tych początkowych informacji o konfiguracji oprogramowania można je wykorzystać do przetwarzania obrazów wideo na żywo poprzez wyszukiwanie pozycji w przetwarzanym obrazie, które reprezentują najlepsze dopasowanie z wcześniej zgromadzonymi cechami wzorcowy$\mathrm{mi}, \mathrm{z}$ zastosowaniem wzoru

$$
F_{m e}[i]=\sum_{J=0}^{F_{s}}\left|R_{f}[j]-I_{m}[i+J]\right| \text { dla } 0 \leq i<I_{w}
$$

gdzie: $F_{m e}$ jest dopasowaniem cechy lub macierzą wartości błędu korelacji, $F_{s}$ jest rozmiarem cechy wzorcowej w pikselach, $R_{f}$ jest jednowymiarową macierzą przechowującą wartości intensywności cechy wzorcowej, a $I_{m}$ jest intensywnością pikseli żywego obrazu w pozycji i podczas przemieszczania się od lewej przy poziomej pozycji kalibracji

Po ukończeniu obliczeń błędu dopasowania, macierz błędu dopasowania cechy $F_{\text {me }}$ jest wyszukiwana dla pozycji, przy której występuje najmniejszy błąd korelacji, co odpowiada najlepszemu dopasowaniu przetwarzanej cechy, jak pokazano w równaniu.

$$
\mathrm{B}_{\mathrm{m}} \leftarrow \min \left\{\mathrm{F}_{\text {me }}[\mathrm{i}] \text { dla } 0 \leq \mathrm{i}<\mathrm{I}_{\mathrm{w}}\right\}
$$

Wartość $B_{m}$ w równaniu (2) odpowiada najlepszemu dopasowaniu cechy podczas ruchu z lewej do prawej przy poziomej pozycji kalibracji. Dlatego pozycja pozioma w obrazie, reprezentowana poprzez wartość i, która oddaje najniższy błąd korelacji $B_{m}$, jest miejscem najlepszego dopasowania cechy przetwarzanej. Działanie algorytmu korelacji polepsza się poprzez wyszukiwanie jedynie umiejscowienia cechy lewej dla lewej pozycji kalibracji. Podobny sposób obliczenia dla najbardziej prawdopodobnego dopasowania prawostronnej cechy wzorcowej podejmuje się w miejscach, które znajdują się na prawo od pozycji kalibracji na przetwarzanym obrazie. Przetworzony obraz i odpowiadający mu wykres powierzchni błędu korelacji pokazano na rys. 4.

Krzyżyki po lewej i po prawej stronie rys. 4a pokazuja wykryte pozycje krawędzi jeziorka spawalniczego. Linia wykreślona w poprzek dolnej $1 / 3$ części rys. 4a przedstawia znormalizowane jednowymiarowe przedstawienie wyliczonego błędu korelacji. Dwa najniższe wgłębienia w tej linii przedstawiają pozycję najmniejszego błędu korelacji, a przez to najlepsze dopasowanie z cechami krawędzi wzorcowych. Trójwymiarowe przedstawienie błędu korelacji pokazano na wykresie powierzchniowym na rys. 4b.

Wyraźnie punkty najlepszej korelacji z cechami krawędzi pojawiają się przy ok. 100 i 500 pikseli szerokości obrazu. Jak pokazano na rys. 5 , użycie impulsowego łuku przy spawaniu stali Inconel spowodowało duże zmiany intensywności w obrazach spoiny. Nadmierna intensywność bądź nasycenie obrazu wysokiego impulsu, jak pokazano na rys. 5b, może spowodować trudności z wiarygodnym przetworzeniem danych.
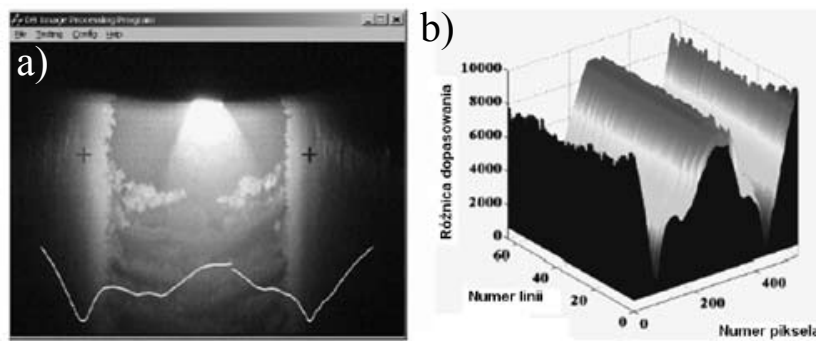

Rys. 4. Przetworzone obrazy spoiny: a - impulsowe spawanie TIG prądem stałym na stali Inconel 718, b - wykres powierzchniowy korelacji Fig. 4. Processed weld images: a - pulsed DC TIG on Inconel 718, b - correlation surface plot
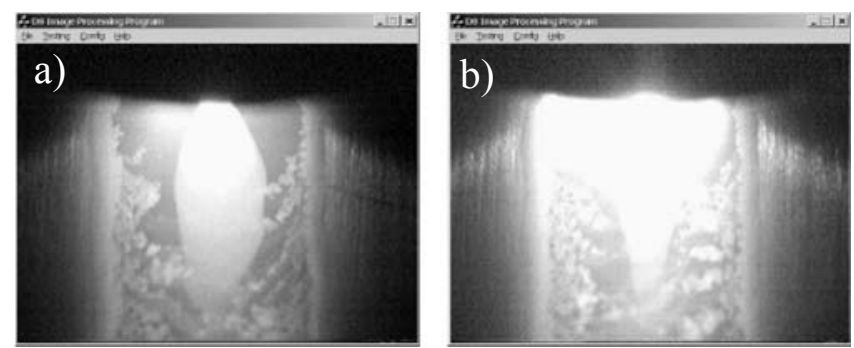

Rys. 5. Jakość obrazu blachy Inconel 718 uzyskiwana zależnie od pulsowania łuku: a - obraz prądu bazy, b - obraz prądu impulsu

Fig. 5. Inconel 718 image quality variation due to arc pulsing, a - low pulse image, $b$ - high pulse image

Aby rozwiązać ten problem, ulepszono algorytm przetwarzania, żeby program mógł rozróżnić, kiedy przetwarzany jest łuk wysokiego (prąd impulsu), a kiedy niskiego impulsu (prąd bazy). Osiągnięto to dzięki wyliczeniu średniej intensywności przetwarzanego obrazu z lewej do prawej przy wcześniej zdefiniowanej pozycji kalibracji.

Następnie do rozróżnienia intensywności łuku impulsu i łuku bazy użyto zmiennego progu. Do wykonania bardziej stabilnego pomiaru, w zależności od jakości obrazu, zastosowano wykluczenie przetwarzania łuku impulsu lub łuku bazy.

W przykładzie pokazanym na rys. 5, w celu poprawienia wyników, przetwarzane były jedynie części łuku bazy. Technika korelacji cechy może być stosowana przy różnych metodach spawania, przez konfigurowanie serii parametrów definiowanych przez użytkownika. Aby to zilustrować, na rys. 6 pokazano zestaw cech wzorcowych, przetworzony obraz i wykres korelacji spawania aluminium TIG prądem zmiennym.

Przy spawaniu aluminium widać wyraźnie przejście w poziomie intensywności wokół umiejscowienia krawędzi na obrazie, które występuje mniej więcej w połowie wzdłuż cech wzorcowych (rys. 6a, 6b).

Cechy wzorcowe dla stopu niklu Inconel 718 miały tendencję do wykazywania większego gradientu intensywności bez wyraźnego przejścia przy umiejscowieniu krawędzi jeziorka spawalniczego (rys. 3c, 3b).

Pokazuje to, że obrazy o różnych kształtach cech wzorcowych krawędzi mogą być pobierane przez algorytm przetwarzania obrazu i rzetelnie przetworzone. Kiedy algorytm a)
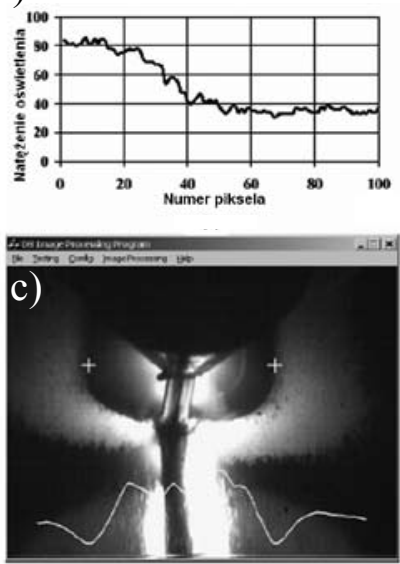

b)

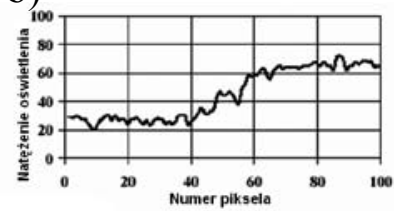

d)

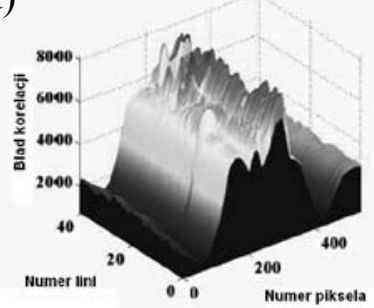

Rys. 6. Spawanie aluminium metodą TIG prądem zmiennym: a - cecha wzorcowa lewej krawędzi jeziorka, b - cecha wzorcowa prawej krawędzi jeziorka, c - przetworzony obraz, d - wykres powierzchniowy korelacji

Fig. 6. AC TIG on aluminium: a - left pool edge reference feature, $\mathrm{b}$ - right pool edge reference feature, $\mathrm{c}$ - processed image, $\mathrm{d}-\mathrm{cor}$ relation surface plot 
przetwarzania obrazu zostanie skalibrowany i poprawnie „nauczony” przetwarzania określonego typu obrazu, parametry konfiguracji, takie jak rozmiary cech krawędzi, intensywności cechy wzorcowej, umiejscowienie kalibracji przetwarzania i ustawienia wykluczenia pulsu łuku, można zapisać w pliku danych cyfrowych. Oprogramowanie przetwarzające przywróci wszelkie zachowane ustawienia, tak że wyuczony algorytm może rozpocząć pracę w stanie gotowym do przetwarzania. Procedura kalibracji i uczenia opisana wcześniej jest konieczna jedynie wtedy, kiedy potrzebne jest przetwarzanie obrazów o klasyfikacji innej niż standardowa.

\section{Sterowanie procesem spawania}

Aby przedstawić sterowanie ze sprzężeniem zwrotnym, zastosowano regulator cyfrowy PID, czyli klasyczny regulator proporcjonalno-całkująco-różniczkujący [11]. Uproszczony schemat pokazano na rys. 7 .

Podstawowe działanie kontrolne polega na porównaniu zmierzonej szerokości górnego lica jeziorka spawalniczego z algorytmu przetwarzania obrazu z wartością zadaną. Jeżeli istnieje różnica pomiędzy zadaną a zmierzoną szerokością jeziorka, stosuje się sterowanie procesem, które jest zdolne dostosować zarówno prąd spawania, jak i szybkość podawania drutu. Aktywne dostosowanie prądu i szybkości podawania drutu umożliwia zrównoważenie zróżnicowania rozmiaru jeziorka spawalniczego. Sterowanie procesem wymaga użycia dwóch niezależnych regulatorów PID, jak pokazano w równaniach (3) i (4).

Równania PID zostały wprowadzone do oprogramowania z użyciem oddzielnego programu, który działał równocześnie z oprogramowaniem przetwarzania obrazu na komputerze kontrolnym. Aby dostosować prąd spawania i szybkość podawania drutu, użyto seryjnego protokołu komunikacyjnego CAN [12]. Wymagało to użycia pary wbudowanych systemów mikroprocesorów działających jako węzły CAN sterujące procesem. Podstawowe działanie tych punktów węzłowych polegało na porównywaniu (odejmowaniu) wartości zadanej z sygnałem analogowym prądu spawania i szybkości podawania drutu urządzenia spawalniczego [13]

$$
\mathrm{V}_{\text {triml }}=\mathrm{K}_{\mathrm{PI}} \mathrm{e}_{\mathrm{bw}}+\mathrm{K}_{\mathrm{II}} \int \mathrm{e}_{\mathrm{bw}}+\mathrm{K}_{\mathrm{DI}}\left(\mathrm{e}_{\mathrm{bw}}-\mathrm{e}_{\mathrm{bW}-1}\right)
$$

gdzie: $V_{\text {trimı }}$ jest dostosowaniem prądu spawalniczego, $e_{b w}$ jest błędem szerokości jeziorka, będącym różnicą między zadaną a zmierzoną szerokością jeziorka, $\mathrm{K}_{\mathrm{pl}}$ jest proporcjonalnym przyrostem prądu, $\mathrm{K}_{\|}$oznacza całkujący przyrost prądu dla ostatnich próbek $\mathrm{x}$, gdzie $\mathrm{x}$ jest liczbą całkowitą $\mathrm{w}$ zakresie od 1 do $100, \mathrm{~K}_{\mathrm{DI}}$ jest różniczkowym przyrostem dla prądu, a $\mathrm{e}_{\mathrm{bw}-1}$ jest poprzednim błędem szerokości jeziorka

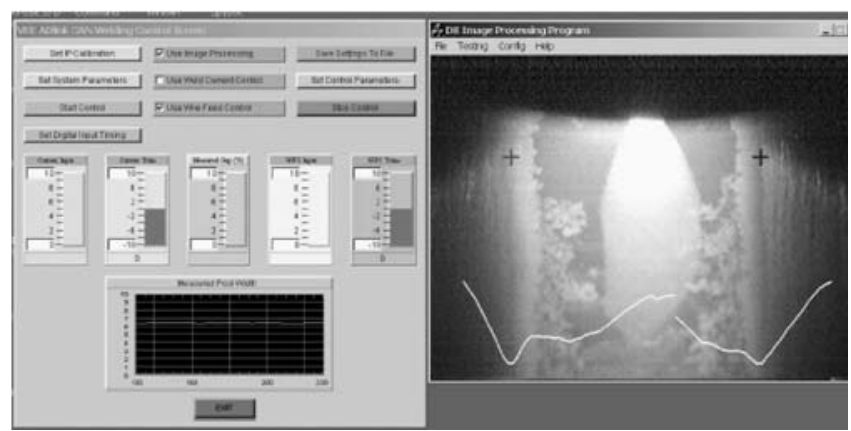

Rys. 8. Oprogramowanie przetwarzania obrazu VEE i Visual C++ Fig. 8. VEE and yisual $\mathrm{C}++$ image-processing software

$\mathrm{V}_{\text {trimWFS }}=\mathrm{K}_{\mathrm{PWFS}} \mathrm{e}_{\mathrm{bW}}+\mathrm{K}_{\mathrm{IWFS}} \int \mathrm{e}_{\mathrm{bW}}+\mathrm{K}_{\mathrm{DWFS}}\left(\mathrm{e}_{\mathrm{bw}}-\mathrm{e}_{\mathrm{bW}-1}\right)$

gdzie: $V_{\text {trimWFs }}$ jest dostosowaniem szybkości podawania drutu, $\mathrm{K}_{\mathrm{PWFS}}$ - proporcjonalnym przyrost szybkości podawania drutu, $\mathrm{K}_{\text {IwFS }}$ - całkującym przyrost szybkości podawania drutu dla ostatnich próbek $\mathrm{x}$, gdzie $\mathrm{x}$ jest liczbą całkowitą w zakresie od 1 do 100 , a $\mathrm{K}_{\mathrm{DWFS}}$ jest różniczkowym przyrosa szybkości podawania drutu.

Rzeczywista implementacja systemu sterowania procesem wymaga użycia graficznego interfejsu użytkownika korzystającego z języka programowania Agilent VEE / 14. Typowy ekran kontrolny komputera pokazano na rys. 8.

Oprogramowanie VEE jest wyposażone w „panel” wyświetlania, pokazany po lewej stronie (rys. 8), który zawiera okna dialogowe, umożliwiające działania takie jak: wybór parametru równania regulatora PID (proporcjonalno-całkująco-różniczkującego) systemu i konfigurację danych z kontroli procesu logowania.

Do pokazania informacji o wartości prądu spawania i ilości podawanego drutu stosuje się serię prezentacji graficznych wraz z wykresem kołowym zmierzonej szerokości jeziorka. Oprogramowanie do przetwarzania obrazu, pokazane po prawej stronie rys. 8, jest wywoływane przez interfejs użytkownika VEE i działa jako równoległy proces komputera kontrolnego. Pomiary z oprogramowania przetwarzania obrazu są przesyłane do systemu sterowania VEE z użyciem wiadomości opartych na modelu klient-serwer za pomocą protokołu TCP/IP [15].

\section{Przebieg i wyniki eksperymentu}

Pierwsza faza eksperymentu wymagała serii prób, które wykonano, aby określić optymalne ustawienie kamery obrazujące górne lico ciekłego jeziorka. W rezultacie zastosowano dwie oddzielne konfiguracje kamery: jedną dla aluminium,

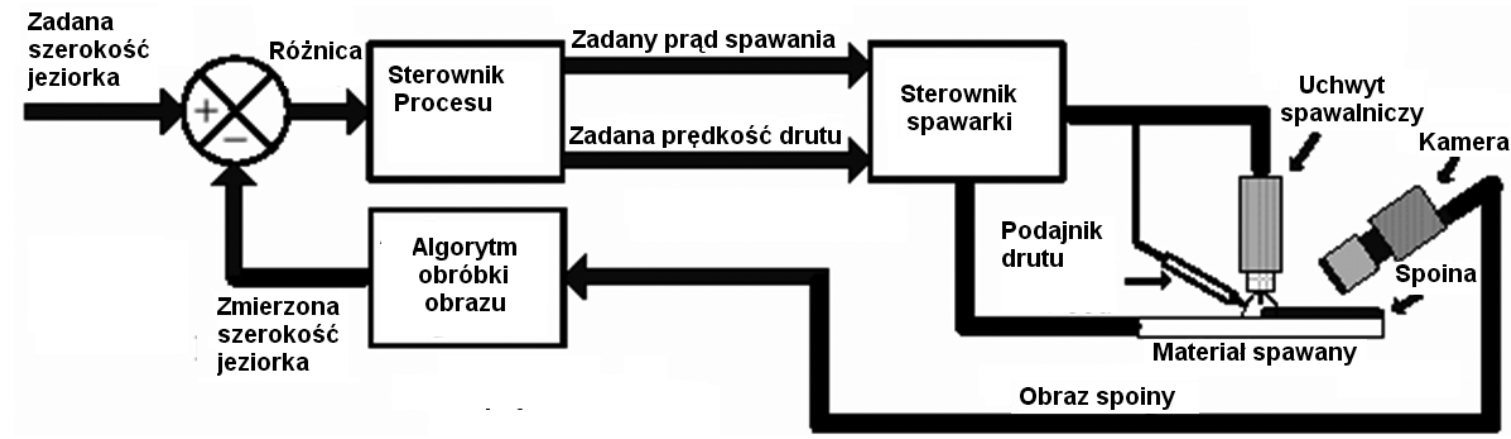

Rys. 7. Schemat systemu sterowania ze sprzężeniem zwrotnym

Fig 7. Closed loop process control schematic 
Tablica I. Parametry spawania aluminium

Table I. Aluminium welding parameters

\begin{tabular}{|l|l|}
\hline \multicolumn{1}{|c|}{ Parametr } & \multicolumn{1}{|c|}{ Wartość } \\
\hline Metoda & TIG AC o częstotliwości $100 \mathrm{~Hz}$ \\
Materiał & aluminium 2024, T4 o grubości 1,6 mm \\
Elektroda spawalnicza & wolframowo-cyrkonowa $\varnothing 3,2 \mathrm{~mm}$ \\
Gaz osłonowy & czysty argon, 15 l/min \\
Szybkość spawania & $3,3 \mathrm{~mm} / \mathrm{s}$ \\
$\begin{array}{l}\text { Prąd spawania } \\
\text { Szybkość podawania } \\
\text { drutu }\end{array}$ & $\varnothing 0 \mathrm{~A}$ \\
& $\varnothing 1,2 \mathrm{~mm}$ typ 5356, szybkość $15 \mathrm{~mm} / \mathrm{s}$ \\
& \\
\hline
\end{tabular}

a drugą dla stopu Inconel. Jak pokazano na rys. 9a, kamera umieszczona na brzegu jeziorka spawalniczego i poniżej poziomu podawania drutu tworzyła bardziej stabilne obrazy spawania TIG aluminium prądem zmiennym. Przy spawaniu stopu Inconel najlepsze wyniki dawało ustawienie kamery za uchwytem spawalniczym, jak pokazano na rys. 9b.

Zgodnie z programem eksperymentu, przeprowadzono następnie serię prób, aby ocenić, czy pomiary szerokości jeziorka oparte na przetwarzaniu obrazu będa stabilne/stałe. Pomiary po spawaniu na rys. 10a są zgodne z pomiarami zautomatyzowanymi na rys. 10b, przy czym każdy wykres pokazuje nominalną wartość szerokości jeziorka około 8 $\mathrm{mm}$. Aby zilustrować problemy, które można napotkać podczas użycia łuku impulsowego, wykonano niekontrolowane napawanie na stopie Inconel z użyciem parametrów, które są przedstawione $w$ tabl. II.

W wykresach na rys. 11 porównano ręczne pomiary szerokości powierzchni jeziorka spawalniczego od strony źródła ciepła po spawaniu, ze zautomatyzowanymi pomiarami z oprogramowania przetwarzania obrazu.

W celu zademonstrowania techniki pomiaru pierwszy etap polegał na porównaniu pomiarów wykonanych ręcznie po spawaniu z pomiarami powierzchni jeziorka spawalniczego od strony źródła ciepła, wykonanymi za pomoca przetwarzania obrazu. Wykresy pomiarów wykonanych dla niekontrolowanego procesu napawania aluminium TIG prądem zmiennym z użyciem parametrów pokazanych w tabl. I, przedstawiono na rys. 10 .
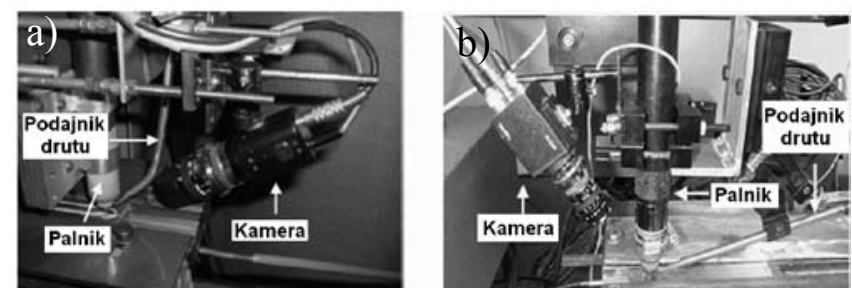

Rys. 9. Praktyczne ustawienia obrazowania spoiny: a - spawanie aluminium TIG prądem zmiennym, b - spawanie stopu Inconel Fig. 9. Practical weld imaging arrangements, $a-A C$ TIG welding with aluminium, $b$ - Inconel welding a)

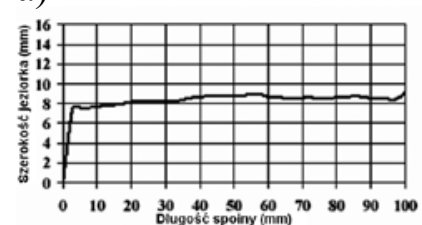

b)

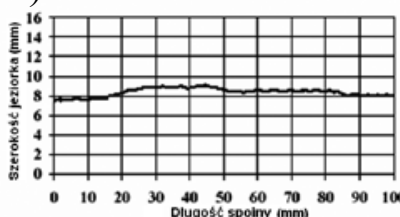

Rys. 10. Pomiary spawania aluminium metodą TIG prądem zmiennym: a - ręcznie zmierzona szerokość górnego jeziorka, b - zautomatyzowany pomiar szerokości górnego jeziorka

Fig. 10. AC TIG on aluminium weld measurements, a - manually measured upper pool width, b - automated upper pool width measurement
Tablica II. Parametry spawania stali Inconel

Table II. Inconel welding parameters

\begin{tabular}{|l|l|}
\hline \multicolumn{1}{|c|}{ Parametr } & \multicolumn{1}{c|}{ Wartość } \\
\hline Metoda & impulsowe TIG DC o częstotliwości $2 \mathrm{~Hz}$ \\
Materiał & blacha stali Inconel 718 o grubości $2,0 \mathrm{~mm}$ \\
Elektroda spawalnicza & wolframowo-cyrkonowa ø $3,2 \mathrm{~mm}$ \\
Gaz osłonowy & czysty argon, 14 I/min \\
Gaz formujący & czysty argon, 18 I/min \\
Szybkość spawania & $1,5 \mathrm{~mm} / \mathrm{s}$ \\
Prąd spawania & $100 \mathrm{~A}$ prąd impulsu (wysoki ), 30 A prąd \\
& bazy (niski) \\
Czas impulsu & $250 \mathrm{~ms}$ wysoki i 250 ms niski \\
Podawanie drutu & $\varnothing 0,8 \mathrm{~mm}$ Inconel 718, szybkość $10 \mathrm{~mm} / \mathrm{s}$ \\
\hline
\end{tabular}

Wykres na rys. 11b pokazuje wpływ spawania łukiem impulsowym na stabilność zautomatyzowanego pomiaru, przy czym zmierzony rozmiar jeziorka ma tendencję wzrostową w synchronizacji z częstością pulsowania łuku. Dzieje się tak przede wszystkim w związku z dużymi odchyleniami intensywności obrazu kamery przy zastosowaniu łuku impulsowego. Aby ominąć ten problem, zastosowano wykluczenie wysokiego impulsu łuku. Wymagało to takiej konfiguracji oprogramowania przetwarzania obrazu, aby pomiary jeziorka były wykonywane jedynie w czasie impulsu niskiego natężenia prądu bazy. Spowodowało to bardziej stabilny pomiar pokazany na rys. $11 \mathrm{c}$, który jest zgodny $z$ ręcznie wykonanymi odczytami szerokości jeziorka, wykreślonymi na rys. 11a.

Końcowa faza eksperymentu wymagała przedstawienia systemu sterowania ze sprzężeniem zwrotnym. Do tych badań wybrano parę blach Inconel o grubości $2 \mathrm{~mm}$, ze skokowym przejściem do grubości 1,4 mm mniej więcej w połowie próbki.

Celem tej fazy badań było uzyskanie porównania między próbkami spawania sterowanego i niesterowanego materiału wykazującego nagłą zmianę grubości. Badania przeprowadzono w celu zademonstrowania działania systemu sterowania ze sprzężeniem zwrotnym.

Do wdrożenia regulacji szerokości powierzchni jeziorka spawalniczego od strony źródła ciepła przy spoinach kontrolowanych użyto proporcjonalno-całkującego (PI) regulatora prądu spawania. Zadano $6 \mathrm{~mm}$ szerokość jeziorka spawalniczego, a prób eksperymentalnych użyto do wykazania, że przyrost proporcjonalny $\mathrm{K}_{\mathrm{PI}}=1 \mathrm{i}$ przyrost całkowy $\mathrm{K}_{\|}=0,01$ wytworzyły akceptowalne wyniki. Po spawaniu, dla każdej wytworzonej spoiny wykonano pomiary powierzchni jeziorka spawalniczego od strony źródła ciepła i od strony przetopu, jak pokazano na rys. 12 .
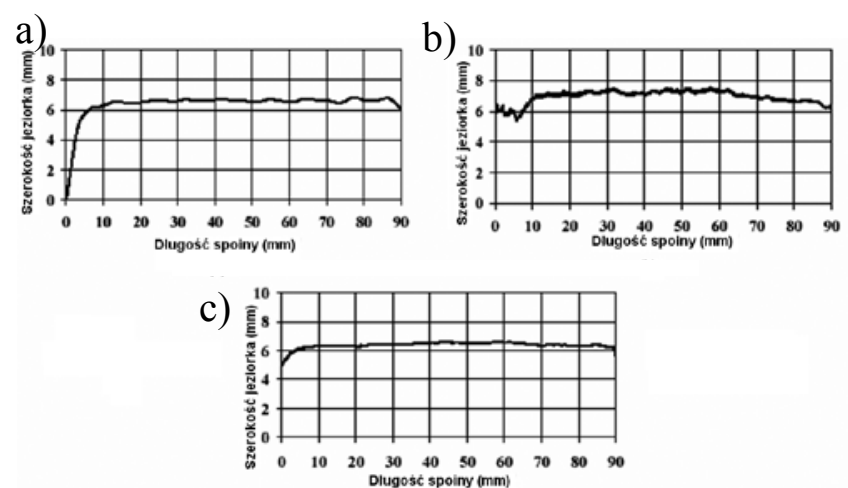

Rys. 11. Pomiary spawania stali Inconel 718: a - ręcznie zmierzona szerokość jeziorka od strony źródła ciepła (lica), b - zautomatyzowane pomiary szerokości jeziorka od strony źródła ciepła, c - zautomatyzowane pomiary z wykluczeniem wysokiego impulsu

Fig. 11. Inconel 718 measurements: a - manually measured upper pool width, $\mathrm{b}$ - automated upper pool width measurement, c - automated measurement with high pulse exclusion 

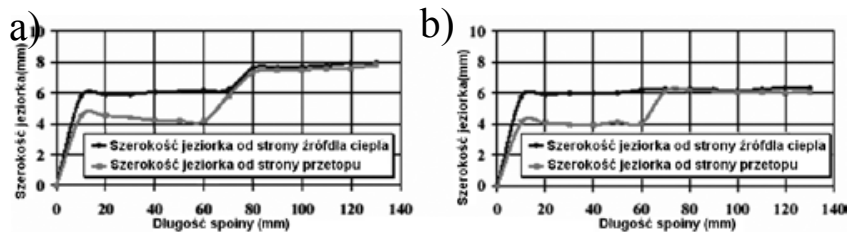

Rys. 12. Pomiary szerokości jeziorka po spawaniu: a - spawanie niekontrolowane, b - spawanie kontrolowane

Fig. 12. Post weld pool width measurements: a - uncontrolled weld, b - controlled weld,

\section{Wnioski}

Technika przetwarzania obrazu, oparta na korelacji cechy domeny przestrzennej, rozwinęła się dzieki dążeniu do niezawodnego przetwarzania wysokiej jakości obrazów z kamery górnego lica jeziorka spawalniczego. Użycie procedury kalibracji i pary wzorcowych cech krawędzi z obrazów próbnych umożliwiło zastasowanie nowatorskiego i wydajnego algorytmu analizy, który może wykonać pomiary szerokości powierzchni jeziorka spawalniczego od strony źródła ciepła w czasie rzeczywistym. Oprogramowanie do przetwarzania obrazu jest całkowicie konfigurowalne, a więc może zostać przystosowane lub można je „nauczyć” radzenia sobie z obrazami różnych procesów spawania. Wykazano to poprzez prezentację wyników pomiarów dla stopu Inconel i aluminium: potwierdziły one akceptowalne (co do wyników) działanie techniki pomiaru dla spawania TIG różnych materiałów.

Dalsze udoskonalenie algorytmu przetwarzania polegało na wprowadzeniu progu średniej intensywności obrazu. Pozwoliło to odróżnić wysoką część impulsowego łuku spawalniczego (prąd impulsu) od niskiej (prąd bazy). Algorytm przetwarzający może zostać tak skonfigurowany, aby wykluczyć pomiary wykonane podczas fazy łuku wysokiego bądź niskiego. Umożliwia to wykonanie bardziej stabilnych pomiarów poprzez efektywne przetwarzanie jedynie określonego zakresu intensywności obrazu, co sprawia, że technika przetwarzania wykazuje większą tolerancję na duże odchylenia w intensywności obrazu, które występują często podczas stosowania łuku impulsowego. System sterowania procesem ze sprzężeniem zwrotnym został wdrożony w formie dwóch równań regulatora proporcjonalno-całkująco-różniczkującego PID, które umożliwiają regulację szerokości powierzchni jeziorka spawalniczego od strony źródła ciepła do wartości zadanej, poprzez dostosowanie prądu i szybkości podawania drutu. Kontrola procesu polegała na porównaniu kontrolowanych
Dla kontrolowanych spoin regulacja szerokości powierzchni jeziorka spawalniczego od strony źródła ciepła również zmniejszyła stopień wtopienia spoiny. Wyraźnie ilustruje to zwiększona jednorodność na wykresie pomiarów po spawaniu szerokości powierzchni jeziorka spawalniczego od strony źródła ciepła i od strony przetopu (górnej i dolnej), pokazanych na rys. $12 b$, w porównaniu $z$ odpowiednimi pomiarami przy spawaniu niekontrolowanym, co zostało pokazane na rysunku 12a. i niekontrolowanych spoin na stopie Inconel, które wykonano przy tych samych parametrach spawania.

Jako krańcowy test systemu sterowania zastosowano skokową zmianę grubości blachy. W sterowanym spawaniu do regulacji szerokości lica jeziorka spawalniczego od strony źródła ciepła zastosowano regulację prądu spawania za pomocą regulatora proporcjonalno-całkującego $\mathrm{PI}$.

Rozwiązanie to pozwala na skuteczną regulację szerokości jeziorka spawalniczego od strony źródła ciepła i ma wpływ na głębokość wtopienia spoiny dla próbki testowej ze skokową zmianą grubości w połowie drogi spawania. W wyniku tego badania jednoznacznie stwierdzono, w jaki sposób systemy sterowania spawaniem z komputerową analizą obrazu mogą być użyte do wytworzenia spoin o stałym profilu wówczas, gdy w trakcie procesu zmienią się warunki odprowadzenia ciepła.

Omówione doświadczenia wykonano z użyciem komputera PC ze standardową, niedrogą kartą telewizyjną WinTV i oprogramowaniem stworzonym dla układu regulacji za pomocą nowoczesnych języków programowania wizualnego. Dlatego eksperymentalny układ regulacji spawania omówiony $w$ tym opracowaniu uważa się za prototyp układu o potencjalnym zastosowaniu komercyjnym. W przyszłości należy zbadać możliwość odejścia od przestarzałej obecnie techniki wideo $w$ formacie Windows i wdrożenia interfejsu bardziej nowoczesnego oprogramowania rejestracji obrazu w formacie ActiveX. Powinno to umożliwić szersze połączenie urządzeń rejestracyjnych z oprogramowaniem przetwarzania obrazu.

Dalsze udoskonalanie metod analizy obrazu i algorytmu pomiaru może pozwolić na zbadanie potencjalnych strategii akomodacji odchyleń jakości obrazu i szczegółowych cech krawędzi, tak aby można było opracować bardziej tolerancyjną technikę pomiaru.

\section{Literatura}

[1] I.S. Kim, Y.J. Jeong, P.K.D.V. Yarlagadda: „Prediction of welding parameters for pipeline welding using an intelligent system", Int. Jnl. of Adv. Man. Tech. 22 (9-10) 2003.

[2] C. Balfour, J. Lucas, S. Maqbool, J.S. Smith, S. Maqbool, L. Meilroy: „Aneural Network Model for MIG Welding Parameter Prediction”, Proc. 10th Int. Conf. On Computer Technology in Welding, June 2000.

[3] J. Gaqo, C. Wu: „Extracting weld penetration information in tungsten-inert gas welding", Proc. of Inst. of Mech. Engn. Part B Jnl. of Eng. Man. 216 (2) 2002.

[4] J. Zhao, M.A. Houghton, C. Balfour, J.S. Smith and J. Lucas: „Real Time Image Processing for Penetration Control In Automated Welding", Proc. 8th Int. Conf. on Computer Technology in Welding, June 1998

[5] H. Luo, R. Devanathan, J. Wang, X. Cheng, Z.Sun: „Vision based neurofuzzy logic control of weld pool geometry", Sci. and Techn. of Welding and Joi. 7, (5) 2002.

[6] Y. M. Zhang, R. Kovacevic: „Neurofuzzy model-based predictive control of weld fusion zone geometry", IEEE Trans. on Fuzzy Sys. 6 (3) 1998.
[7] D.B. Zhao, S.B. Chen, L. Wu, M. Dai, Q. Chen: „Inteligent control for shape of the weld pool in pulsed GTAW with filler metal", 80 (11) (2001).

[8] B. Zaration: "Microsoft Visual C++6.0 programmer,s guide", Microsoft Press (1998).

[9] J. Weiskamp, N.Johnson, F. Gauldt and M. Florence: „How to Digitize Video", Wiley (1994).

[10] M. Sonka, V. Hlavac, R. Boyle: „Image Prosessing, Analysis and Machine Vision", 2nd. end. PWS Publishing (1999).

[11] C.L. Phillips, H.T. Nagle: „Digital Control System Analysis and Design", 3rd cdn. Prentice-hall (1995).

[12] "CAN Specification Version 2.0", Robert Bosh GmbH. (1991)

[13] C. Balfonr, J.S. Smith: „Controller Area Network (CAN) Applied to Welding Systems", Proc. 12th Int. Conf. on Computer Technology in Welding, sierpień 2002.

[14] „VEE Proc User's Guide”, Agilent Technologies Inc. (2000).

[15] K. Gregory, „Using Visual C++.Net”, Que/Sams publishing (2002).

Z języka angielskiego tłumaczyli: Ilona Pawlik i Adam Jastrzębski z Instytutu Łączenia Metali w Krakowie 